\title{
The Effect of Classroom Management and Teacher Work Ethics on Student Learning Outcomes
}

\author{
Nendrawati $^{1 *)}$, Yasir Arafat ${ }^{2}$, Yenny Puspita ${ }^{2}$ \\ ${ }^{1}$ SD Negeri Banding Agung \\ ${ }^{2}$ Universitas PGRI Palembang \\ *Corresponding author. Email: nendrawati28@gmail.com
}

\begin{abstract}
The study aims to analyze the effect of teachers' classroom management and work ethics on student learning outcomes in Public Elementary School (SDN) in Banding Agung district. The areas are to find out: 1) the effect of classroom management on learning outcomes; 2) the effect of teacher work ethics on student learning outcomes; and (3) the effect of classroom management and teacher work ethics together on student learning outcomes. To obtain the accurate results, in this paper the writer uses the quantitative approach. The research subjects were the number of teachers in SDN Banding Agung District. The data collection technique used was a questionnaire technique with the form of a scale. The prerequisite stage of the analysis included normality, homogeneity, linearity test, multicollinearity test, and data autocorrelation test. The research hypothesis was tested by using multiple regression. The data collection technique was carried out by means of a questionnaire distributed to the teacher. After analyzing the data, the following results were obtained: 1) Classroom management has a positive and significant effect on the learning outcomes based on the value of $t$ count which is greater than $t$ table. The value of $t$ table is 8.083 which is greater than t table (3.11); 2) Teacher work ethics has a positive and significant effect on the student learning outcomes based on the results of the calculation. The value of $t$ count is greater than $t$ table $(8.920$ and 3.11$)$; (3) the classroom management and teacher work ethic have a positive and significant effect on student learning outcomes according to calculation of Fcount. F count is greater than $\mathrm{F}$ table (53.928 and 1.86).
\end{abstract}

Keywords: Class management, Work ethics, Students’ learning

\section{INTRODUCTION}

School is a complex and unique institution. Its complexity is due to the posisition in a complicated system order. The school is unique since it has its own characteristics that are not shared by the other organizations in which a place for teachers and student to hold the planned and organized teaching and learning activities. School as a system has three main aspects that are closely related to school quality. The aspects are the teaching and learning process, leadership, and school management. Schools are responsible for improving the the quality of education so that changes in values are needed, both in the school management system and in the learning system. Therefore, a school must be managed in a good management.

Teachers have an important role in the success of learning in schools. They are responsible to help students in achieving the goal of life optimally. In the classroom the teacher carries out two main activities, namely teaching and class management activities. Teaching activities are the process of organizing the environment around students. All teaching components which include objectives, learning materials, teaching and learning activities, methods, tools and resources, and evaluation are performed optimally in order to achieve the teaching objectives that have been set before teaching is carried out. The educational process is in the form of a process of implementation and success at all levels. In addition, the essence of the educational process is in learning. Referring to the government regulation number 32 article 1 section 19 year 2013 , learning is a process of interaction among students, between students and educators, and between students and learning resources in a learning environment. To realize an effective interaction, teacher professionalism is 
needed in building and managing the learning process in the classroom.

Learning is essentially a reciprocal transactional communication process either between teachers and students or among students to achieve predetermined goals. Referring to the constitution number 14 of 2005 concerning teachers and lecturers in article 10, teacher (educator) is the key to success (determinant factors) in creating the quality of education Teacher is the one who determine the factors in supporting the success of learning and improving the quality of education. Teachers are human resources who are at the forefront of the teaching and learning process.

Furthermore, learning outcomes are essential and cannot be separated from the learning process. Learning outcomes are the measurement of the success of a learning process. With learning outcomes, teachers can find out whether students have reached the predetermined competencies. Learning outcomes are the results that someone has achieved after going through the learning process by first providing an evaluation after the learning process takes place. Learning outcomes can be in the form of changes in behavior which include the cognitive, affective and psychomotor domains. Learning outcomes are usually expressed in numbers. High or low learning outcomes indicate the success of the teacher in delivering subject matter in the learning process, classroom management and good teacher work ethic, which includes student abilities, the ability of teachers to deliver learning material, and the environment around students.

Classroom management and teacher work ethic in the learning process can affect the level of student learning outcomes. Class management and good work ethic can stimulate student activity during the learning process. Teachers have to pay attention carefully in choosing what methods are appropriate to use in a lesson and should avoid using monotonous methods that can make students feel bored. Accordingly, the ability of students in receiving learning material delivered by the teacher also affects learning outcomes. Ideally, primary school student learning outcomes must reach 65 based on the minimum completeness criteria (KKM). Students' success in learning is if the scores obtained by students can meet the KKM that has been approved by the school.

The teacher's role is very important in classroom management. The teacher not only has a duty to be a manager in class management, but also delivers materials. An effective management can make students feel comfortable and enthusiastic to participate in classroom learning. Teachers will also find it easier to convey material to students if the class has been conditioned from the beginning of learning. Less optimal classroom management implementation will result in low student learning outcomes. Rifai'i and Anni [1] state that learning outcomes are changes in behavior obtained by students after experiencing learning activities. Another opinion expressed by Karwati and Priansa [2] that the learning outcomes students may do are as the result of their learning activities. According to Sudjana [3], learning outcomes are the abilities that the students have after receiving their learning experiences. According to Bloom (in Sudjana [3]), student learning outcomes can be classified into three domains, namely the cognitive domain which includes knowledge; the affective domain which relates to the student attitudes, and the psychomotor domain that refers to the student skills. To achieve the quality learning outcomes in these three domains, a quality learning process must be designed by paying attention to the level of thinking that will be learned by students.

Classroom management is an effort made by a teacher in charge of learning activities with the aim of achieving optimal conditions so that learning activities can be carried out as expected [4].

An effective classroom management always begins with: 1) Checking class attendance; 2) Collecting student work results to check and assess work results; 3) Distributing tools and materials; 4) Collecting information from students; 5) Recording data; 6) Archiving maintenance; 7) Delivering the subject matter; and 8) Giving assignments. An effective learning activity means the learning process in which each element functions as a whole; participants feel engaged in the learning outcomes; and there provide adequate facilities, material and professional teachers. Classroom management is not only in the form of classroom arrangements, but also the physical facilities and routines. Classroom management activities are intended to create and maintain a comfortable classroom atmosphere and conditions. Thus, the teaching and learning process can take place effectively and efficiently such as providing reinforcement, developing teacher-student relationships and making productive group rules.

The influence of the teacher is very essential on the development of students so the teacher is required to be able to carry out their duties and responsibilities optimally. There is an influence between increasing learning outcomes and increasing human resources. Classroom management is an effort made by the teacher in charge of learning activities with the aim of achieving optimal conditions so that learning activities can be carried out as expected [5].

Moreover, teacher's work ethic is very important because it involves motivation, spirituality, principles, code of ethics, and a person's belief to carry out work seriously. Every teacher should have a high work ethic 
because the success of learning requires hard work and high commitment from the teachers.

If the teacher does not have a high work ethic, learning will not achieve the expected goals so that the objectives of the educational process will neither be achieved. To achieve educational goals, teachers who have a high work ethic are aware of their function in the classroom not merely as a source of knowledge, but as the facilitators and mediators for students to achieve an effective learning.

A competent teacher is a teacher who creatively facilitates student learning, one of which is by using learning media. Learning media mean anything that are used to convey messages. The learning media relate to anything that have the purpose of intermediary for conveying messages whether in the form of oral or visual aids indicating a specific purpose. The media can be understood by students in receiving the message [6]. The research is designed as in the following:

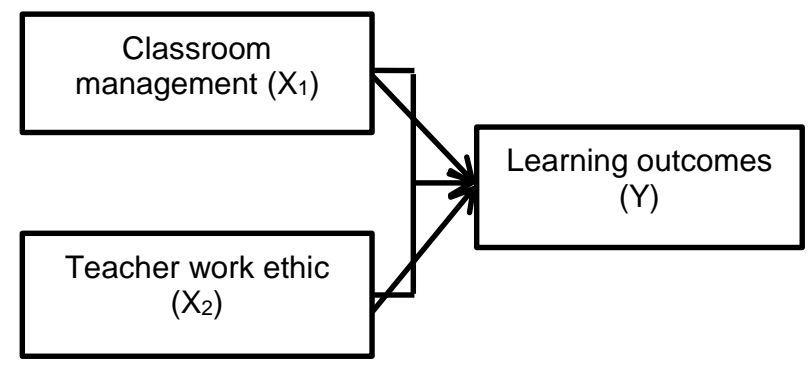

Figure 1. Design of the research

Based on the above figure, the hypothesis can be formulated as follows: a) There is an effect of classroom management on student learning outcomes at SDN 03 Banding Agung District; b) There is an effect of teacher work on student learning outcomes at SDN 03 Banding Agung District; and c) There is an effect of classroom management and teacher work ethic on the student learning outcomes at SDN 03 Banding Agung District.

\section{METHOD}

The research is designed as a descriptive method. It seeks and describes the interpreted objects as the way they are [7]. This research was conducted by using a quantitative approach. A simple quantitative approach refers to data collection carried out by using an instrument method namely the survey method by giving questionnaires to respondents. This study uses an explanatory survey method. In accordance with the purpose, the study explains the relationship between variables of classroom management and teacher work ethics on student learning outcomes at SDN 03 Banding Agung district.

The population of this study was all teachers in SDN Banding Agung District. The sampling technique used is the probability sampling technique with the simple random sampling method. It takes samples from members of the population randomly without paying attention to the strata or levels in the members of the population. The members of the population are considered homogeneous [8]. The determination of the research sample from the population is at least $50 \%$.

To assure the validity of data collection, it is necessary to have the appropriate instrument so that the research can discover what is going to find. The research instrument used in data collection in the study was a questionnaire. A questionnaire is a data collection technique which is done by giving a set of questions or written statements to respondents to be answered.

\section{RESULTS AND DISCUSSION}

\section{The hypothesis test}

Hypothesis test was continued after testing the normality and the homogeneity test. After the data were collected by using the requirements to be tested, then the hypothesis is tested by using the t test and $\mathrm{f}$ test to determine the effect partially and simultaneously on the tested variables.

\section{The hypothesis test 1}

The result of statistical analysis which aims to find out if classroom management (X1) effect on student learning outcomes (Y).

Table 1. The results of t-test analysis of classroom Management Variables (X1) on Learning Outcomes Variables (Y)

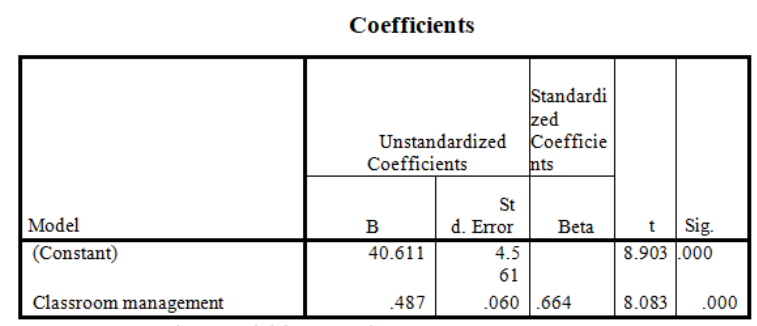

a. Dependent Variable: Learning outcomes

Based on the results of the $t$ test $\mathrm{X} 1$ against $\mathrm{Y}$ above, it is found that the significance value is 0.000 . The significant value (probability) is smaller than 0.05 meaning $\mathrm{Ho}$ is rejected and $\mathrm{Ha}$ is accepted. Thus, classroom management has an influence on the learning outcomes in the value of $0.000<0.05$, and the $\mathrm{t}$ value is $8.083>\mathrm{t}$ table 3.11 . It can be concluded that $\mathrm{Ha} 1$ is accepted, and there is an influence of $\mathrm{X} 1$ on Y.

\section{The hypothesis Test 2}

The results of correlation statistical analysis to find out if the teacher's work (X2) effects on learning outcomes (Y). 
Table 2. The results of t-test analysis of teacher work ethic variables (X2) on learning outcomes (Y)

Coefficients

\begin{tabular}{|c|c|c|c|c|c|}
\hline & \multicolumn{2}{|c|}{$\begin{array}{l}\text { Unstandardiz } \\
\text { ed Coefficients }\end{array}$} & \multicolumn{3}{|l|}{$\begin{array}{l}\text { Standardized } \\
\text { Coefficients }\end{array}$} \\
\hline $\begin{array}{c}\text { Model } \\
\text { (Constant) }\end{array}$ & $\begin{array}{c}\text { B } \\
38 . \\
339\end{array}$ & $\begin{array}{r}\text { Std. } \\
\text { Error } \\
4 \\
.389\end{array}$ & Beta & $\begin{array}{r}\mathrm{t} \\
8 \\
.736\end{array}$ & $\begin{array}{r}\text { Sig. } \\
.00 \\
0\end{array}$ \\
\hline Work Ethics & $\begin{array}{r}.55 \\
1\end{array}$ & $062^{\circ}$ & .700 & $\begin{array}{r}8 \\
920\end{array}$ & $\begin{array}{r}.00 \\
0\end{array}$ \\
\hline
\end{tabular}

a. Dependent Variable: Learning Outcomes

Based on the results, it was found that the significance value is 0.000 . The significant value (probability) is smaller than $0.05 \mathrm{~T}$, thus $\mathrm{Ho}$ is rejected. This means that $\mathrm{Ha}$ is accepted that means work ethic has an influence on learning outcomes in $0.000<0.05$ and the $t$ value of $8.920>t$ table 3.11. It can be concluded that $\mathrm{Ha} 2$ is accepted. On the other word, there is an influence of $\mathrm{X} 2$ on $\mathrm{Y}$.

\section{The hypothesis Test 3}

This hypothesis is carried out with the statistical analysis of the double-grade score to determine the relationship between the independent variables and the dependent variable

Table 3. The result of Regression Test

\begin{tabular}{lclllll}
\multicolumn{8}{c}{ ANOVA $^{\mathrm{b}}$} & & & \\
\hline \multicolumn{1}{c}{ Model } & Sum of & & & & \\
1 & Squares & df & Mean Square & F & Sig. \\
& Regression & 1773.758 & 2 & 886.879 & 53.928 & $.000^{\mathrm{a}}$ \\
& Residual & 1348.548 & 82 & 16.446 & & \\
\hline
\end{tabular}

a. Predictors: (Constant), Class Management, Work Ethic

b. Dependent Variable: Learning Outcomes

Based on the value above, it is known that the significance value for the effect of X1 and X2 simultaneously on $\mathrm{Y}$ is $0.000<0.005$, and the value of F count 53.928> F table 1.86. It can be concluded that $\mathrm{H} 3$ is accepted. Thus, there is an effect of X1 and X2 on $\mathrm{Y}$.

\section{Discussion}

\section{The Effect of Classroom Management (X1) on Learning Outcomes ( $Y$ )}

The hypothesis test 1 was carried out by using regression analysis of the SPSS version 21 program. Based on the regression results for the class management variable on learning outcomes it was found that there was a significant influence between class management on student learning outcomes at SDN Banding Agung District. The value was 0.000 $<0.05$ and the value of $t$ count 8.083> $t$ table 3.11. It can be concluded that Hal is accepted, which means that there is an effect of class management variables (X1) on student learning outcomes (Y) in Cluster 03 SDN Banding Agung District

The results are similar to a study conducted by Ina Nurlina's [9] which is entitled "The effect of classroom management and work ethic on the effectiveness of the teaching and learning process of elementary school teachers in Babkancikao subdistrict of Purwakarta district". The study indicates that simultaneous class management and work ethic greatly influence the effectiveness of the teaching and learning process as evidenced by $\mathrm{F}$ counting 3,928. An effective classroom management supported by a good teacher work ethic will certainly result in an effective learning process, and of course will produce good student learning outcomes as well.

Based on the research results and opinions above, there is an effect of classroom management on student learning outcomes. In the context of classroom, students can be viewed from their way of learning, the character, social relation, discipline, and responsibility in the teaching and learning process. The teacher as a class manager should ideally be able to manage the class as an effective learning environment. This environment is regulated and supervised so that the learning activities are directed towards educational goals.

\section{The Effect of Work Ethics (X2) on Student Learning Outcomes ( $Y)$}

In the hypothesis test 2 , the work ethic variable on student learning outcomes is $0.000<0.05$ and the $t$ value is $8.920>\mathrm{t}$ table 3.11 . It can be concluded that $\mathrm{Ha} 2$ is accepted, which means there is an influence of Work Ethic (X2) on Student Learning Outcomes (Y).

The finding is in line with Syahfitri's research [10] entitled "The Relationship of Work Ethics with Class VI Student Learning Outcomes in Public Elementary Schools of Sunnggal. Based on the results of the study, it shows that the work ethic of the teacher is closely related to student learning outcomes. The evidence of the correlation is $r$ count $>\mathrm{r}$ table, namely $0.596>0.444$. It strongly indicates that the work ethic of teachers and student learning outcomes have a high correlation.

Establishing work ethic performed by the principal is hoped to maintain an ethos and attitude of hard work and reflects an adherence to the rules and regulations that have been set in managing and carrying out a job or task. The work attitude that is reflected in the work discipline can be implemented if all school members have a commitment to the rules and regulations that have been mutually agreed including adherence to timeliness, procedures, regulations, rules and attitudes of effective teaching 
and learning activities. For example, the principal makes a letter of assignment accompanied by job descriptions to teachers and employees. Following up on the assignment letter that has been received by teachers and employees, they try to carry out according to their duties and job descriptions. They develop the coordination to motivate school members to work hard, be sincere, be disciplined, dare to take risks, and obey regulations. The principal acts as a catalyst for increasing work ethic. The principal becomes a role model of enthusiasm that can affect the working conditions of school residents. The principal works hard and never gives up in carrying out his main duties and functions. This effort can improve work ethic of school residents. The school principal is expected to create a healthy work atmosphere so that it can form school members with competitive spirit.

Based on the results of research, there is an influence of teacher work ethic on student learning outcomes. In the learning process, apart from the need of effective classroom management, a good teacher work ethic is also needed. A teacher who has a good work ethic has discipline and good sense of responsibility. By having a good work ethic, teachers have the opportunity to help the students have good learning outcomes.

\section{The Effect of Classroom Management and Teacher Work Ethics on Student Learning Outcomes}

In in the hypothesis test 3 , it is known that the significance value for the effect of $\mathrm{X} 1$ and $\mathrm{X} 2$ on $\mathrm{Y}$ is equal to $0.000<0.005$ and $\mathrm{F}$ value of $53.928>\mathrm{F}$ table 1.86. It proves that $\mathrm{H} 3$ is accepted, and there is an effect of classroom management (X1) and teacher work ethic (X2) simultaneously on Y.

This is in line with the research conducted by Anjasari [11] entitled: "The Effect of Classroom Management and Teacher Work Ethics on the Effectiveness of the Learning Process". This results indicate that classroom management has a positive and significant effect on the effectiveness of the learning process based on $t$ count greater than t table (2.168 greater than 2.068). Teacher work ethic has a positive and significant effect on the effectiveness of the learning process based on $t$ table or 28.797 is greater than 2.068. Classroom management and teacher work ethic have a positive and significant effect on the effectiveness of the learning process according to $\mathrm{F}$ count greater than $\mathrm{F}$ table or 409,046 is greater than 3.44. The other factors that can influence are student learning motivation, school organizational climate, work motivation, facilities and infrastructure, loyalty, satisfaction, etc., The relationship between classroom management and teacher work ethics has a positive relationship.

\section{CONCLUSION}

Based on the positive influence between classroom management and the work ethic of the teachers with the student learning outcomes in SDN Banding Agung District, the better the management of class management and teacher work ethics applied to the teaching and learning process in the classroom, the greater opportunities to produce students who have good learning outcomes.

\section{REFERENCES}

[1] Rifa'i, A and Anni, C.A. (2012). Psikologi Pendidikan. Semarang: Universitas Negeri Semarang Press.

[2] Karwati, E., \& Donni, J. P. (2014). Manajemen Kelas: Classroom Management. Bandung: Alfabeta.

[3] Sudjana, Nana. (2016). Penilaian Hasil Proses Belajar Mengajar. Bandung: PT Remaja Rosdakarya.

[4] Ekosiswoyo, R, and Rachman, M. (2000). Manajemen Kelas. Semarang: CV. IKIP Semarang Press.

[5] Djamarah, S. B., \& Aswan, Z. (2013). Strategi Belajar Mengajar. Jakarta: Rineka Cipta.

[6] Sukiman. (2012). Pengembangan Media Pembelajaran. Yogyakarta: Pedajogja.

[7] Sukardi. (2013). Metodologi Penelitian Pendidikan : Kompetensi dan Praktiknya. Jakarta : PT Bumi Aksara.

[8] Riduwan. (2010). Skala Pengukuran Variabelvariabel Penelitian. Bandung: Alfabeta.

[9] Ina Nurlina (2013) dengan judul Pengaruh Manajemen Kelas dan Etos Kerja Terhadap Proses Belajar Mengajar Guru Sekolah Dasar Di Kecamatan Babakan Cikao Kabupaten Purwakarta. semarang. Semarang. Universitas Negeri Semarang.

[10] Safitri, W. (2016) Hubungan Etos Kerja dengan Kemampuan Siswa SD Negeri Sunggal. Universitas PGRI Palembang.

[11] Anjasari, E. (2018) Pengaruh Etos Kerja terhadap Efektifitas Proses Pengajaran. Universitas PGRI Palembang. 